\title{
Assessing the value and market attractiveness of the accessible tourism industry in Europe: a focus on major travel and leisure companies
}

\author{
James Bowtell
}

James Bowtell is based at Loughborough University, Loughborough, UK.
(C) James Bowtell. Published in the Journal of Tourism Futures. This article is published under the Creative Commons Attribution (CC BY 4.0) licence. Anyone may reproduce, distribute, translate and create derivative works of this article (for both commercial and non-commercial purposes), subject to full attribution to the original publication and authors. The full terms of this licence may be seen at http://creativecommons. org/licences/by/4.0/legalcode

\begin{abstract}
Purpose - The purpose of this paper is to examine the accessible tourism market potential, alongside the implications of operating in the accessible tourism market and an assessment of major travel and leisure company involvement. The research focused on providing a market value forecast using historic data from 2005 and extrapolating this to 2025. An examination of the reasons for and against major travel and leisure company involvement in the accessible tourism market was accompanied by an analysis of managerial perceptions.

Design/methodology/approach - The exploration of travel patterns of disabled tourists, in particular spend per head per holiday, was used to measure the value of the demand side of accessible tourism. Semi-structured interviews were carried out with employees of major travel and leisure companies in managerial positions.

Findings - The study indicates that the accessible tourism market is a distinct sector, possessing the capacity for extensive future growth, and thus presents major travel providers with a potentially substantial and lucrative market, generating potential revenues of €88.6 billion by 2025.

Research limitations/implications - Due to a lack of existing data an assumption had to be made on the evolution of travel spend per head per holiday. However, the formula used, using GDP/Capita growth, is a recognised way of forecasting this kind of data in the travel and leisure industry.

Originality/value - This is the first paper to provide an examination of the reasons for and against major travel and leisure company involvement in the accessible tourism market, as well providing a forecast of the market value up to 2025.
\end{abstract}

Keywords Tourism, Disability, Partnerships, Accessible tourism, Market analysis, Travel and leisure

Paper type Research paper

\section{Research highlights}

- The general demand for accessibility in Europe alone exceeded 120 million people in 2005, more than 27 per cent of the European population at the time. It is estimated that by the end of 2025 this demand will reach an approximated 160 million people.

- An analysis of the accessible tourism market size shows that 70 per cent of the population demanding accessibility have both the financial as well as the physical capabilities to travel, generating potential revenues of $€ 88.6$ billion by 2025. This represents a 65 per cent growth rate (2.56 per cent CAGR) from 2005 , when the last paper to conduct this type of research was published. 
- With the ageing of the baby boomer generation and their accompanying burden of disease, future disability rates are expected to increase. It is forecast that 35 per cent of the population in developed countries will be at least 60 years old in 2050. This demographic containing a greater proportion of seniors, unlike past generations, is seeking an active and adventurous experience for their post work lives, and tourism is seen as an important component of their quest for life experiences.

- Research on accessible tourism and spending power of disabled tourists has dispelled the myth that people with disabilities are poor. The German Federal Ministry of Economics and Labour found on average, the disabled tourist spends 1.16 times more than the able bodied tourist.

- There is a very small percentage of the market that addresses the needs for accessible tourism. 63 per cent of major travel and leisure company representatives who took part in this research stated their company did not sell accessible products. Currently there is no comprehensive solution that provides people with disabilities with the same travelling opportunities that an able bodied person has. For this to improve, a combination of increased awareness, education, legislation, partnerships and the resolve to invest in universal design will be required in the travel and leisure industry.

\section{Introduction}

\section{Paper aim}

Accessible tourism is an evolving area of academic study and industry practice (Darcy and Buhalis, 2011). The coming together of an ageing population and focus on inclusion and accessibility has led to an increase in the literature and exploration of theoretical concepts that underpin the developing accessible tourism industry. The accessible tourism market includes tourists with varying levels of accessibility requirements who have been poorly served by the tourism industry (Miller and Kirk, 2002). Previous literature on accessible tourism has often focussed on defining terminology (Darcy, 1998; Aitchison, 2003; Buhalis et al., 2005; Darcy and Buhalis, 2011), analysing theoretical approaches (Darcy, 1998; Buhalis et al., 2005; Darcy et al., 2008b) and focusing attention on issues faced by disabled tourists (Brouillette et al., 1995). An area covered in less detail is major travel and leisure company involvement.

This paper aims to provide an overview of the accessible tourism market potential, by forecasting the market value from 2005 to 2025. The implications of operating in the accessible tourism market will be analysed using an assessment of major travel and leisure company involvement. To examine this, the research is split into two parts:

1. An analysis of the accessible tourism market value.

2. An examination of the reasons for and against major travel and leisure company involvement in the accessible tourism market. This is accompanied with an analysis of perceptions of managers in strategic positions of these organisations.

\section{Literature review}

\section{Definitions of accessible tourism}

Darcy and Dickson (2009, p. 32) define accessible tourism as:

Enabling people with access requirements including mobility, vision, hearing and cognitive dimensions of access, to function independently and with equity and dignity through the delivery of universally designed products, services and environments.

This definition is inclusive of all people including those travelling with children in prams, people with disabilities and seniors.

\section{Definitions of disability}

The World Health Organisation defines disability as:

A restriction or lack (resulting from an impairment) of the ability to perform an activity in the manner, or within the range, considered normal for a human being. 
The World Health Organisation's definition may have been useful in providing some degree of homogeneity to domestic legislation and clinical criteria, however from the perspective of the disabled population it is an inadequate definition of their experience (Brouillette et al., 1995). Rejecting the notions of "normal for a human being" results in a consensus view that some degree of impairment is normal for most human beings, at some point in their lives, and that the restrictions and deprivations experienced by disabled people actually arise from the assumption that they are outside the "norm" (Brouillette et al., 1995). The World Health Organisation (WHO) (2012) has since altered their 1980 definition of disability to:

Disabilities is an umbrella term, covering impairments, activity limitations, and participation restrictions. An impairment is a problem in body function or structure; an activity limitation is a difficulty encountered by an individual in executing a task or action; while a participation restriction is a problem experienced by an individual in involvement in life situations. Thus disability is a complex phenomenon, reflecting an interaction between features of a person's body and features of the society in which he or she lives.

\section{Existing models of disability}

A comparison of two models; the Medical and Social Models of Disability (Buhalis et al., 2005) show an evolution in perceptions toward disability. The traditional medical approach refers to disability as the problem of the individual, a model that serves as the basis for many negative and limiting attitudes, policies and outcomes (Ells, 2001; Vash, 2001). Within the social model approach, which challenges society when looking at disability, there is a focus on service providers and the removal of social and environmental barriers to enable full social, physical and leisure participation (Aitchison, 2003). Changing perceptions, alongside the realisation that only a small percentage of people are born with disabilities is extremely important and will subsequently help to remove existing barriers.

\section{The general demand for accessible tourism}

The general demand for accessibility in Europe alone exceeded 126 million in 2005, more than 27 per cent of the European population at the time (Buhalis et al., 2005). Worldwide this figure exceeded 650 million and it is estimated that by the end of 2020 it will reach an approximated 1.2 billion people (Darcy et al., 2008b, a).

Evidence suggests there is substantial volume in the accessible tourism market, however an analysis of available information demonstrates that only a very small percentage of the market addresses the needs for accessible tourism (Buhalis et al., 2005). It has been estimated that over 25 per cent of European citizens do not take holidays due to perceived barriers to accessible travel (European Commission, 1996).

\section{Evolution of accessible tourism - the demand side}

Increasing disabled population with a focus on mobility. With the ageing of the baby boomer population and their accompanying burden of disease, future disability rates are expected to increase (Rosenberg et al., 2011). Indeed, recent National Health and Nutrition Examination Survey data suggests that for 60-69 year olds, the prevalence of disability in instrumental activities of daily living and mobility is increasing (Brault et al., 2009).

Travel spend and the disabled traveller as a customer. There are a number of benefits tour operators can gain from expanding what is still a relatively new market. People with disabilities have the tendency to become brand evangelists for the brand they love; for example, if a consumer would normally tell five people about their favourite product, people with disabilities could tell 50 (Hsu and Powers, 2002). The myths that persons with disabilities are poor have been proven wrong through research concluding that disabled tourists tend to spend more per day than able-bodied tourists (Horgan-Jones and Ringaert, 2004; Van Horn, 2002). This suggests that sizable spending power exists within the accessible market. According to statistics in a UK report produced by the Department for Culture, Media and Sport (2010) disabled tourists:

- become regular clients after finding a tourism facility that suits their needs; 
- tend to take longer holiday breaks than the average - the average duration of travel undertaken by persons with activity limitations is 13.9 days (holidays) and 3.6 days (short breaks) (BMWA, 2004); and

- tend not to travel alone, as they are often accompanied by caregivers, family and friends: over 50 per cent travel with a partner, 20 per cent with a child and between 21 and 25 per cent with a companion.

According to the US Census Bureau in 2005, the close to 50 million disabled consumers in the USA (the largest minority group in America) have at their disposal $\$ 1$ trillion, a figure which comes as a surprise to marketers (Fost, 1998). Attempting to reach this powerful consumer group certainly makes good "handicapitalism" (a term coined by Prager, 1999), but businesses also see that reaching out to the disabled tourist shows concern for diversity and sensitivity (Williams, 1999).

Research on accessible tourism and spending power of disabled tourists has dispelled the myth that people with disabilities are poor (Buhalis et al. , 2005; Horgan-Jones and Ringaert, 2004; van Horn, 2002). Disabled citizens in Germany for example would be willing to pay between $€ 1000$ and $€ 2000$ more for suitable tourism products and services than the able bodied tourist (BMWA, 2004). In the same study produced the German Federal Ministry of Economics and Labour found on average, the disabled tourist spends 1.16 times more than the able bodied tourist. A variable of disabled tourist travel spend is their disposable income, however those who have lower disposable incomes tend to save more money to spend on holidays. Although disabled tourists are willing to save more for their holidays and spend more while on holiday, the options of where to spend and the comprehensiveness of these choices are severely lacking. If suitable facilities were provided and marketed consistently, the additional spending generated from the disabled customer would be great. In 1993, Deloitte Touch published a study, entitled "Profiting from Opportunities" and identified a potential additional spending of nearly $£ 17$ billion by the disabled tourist in Europe, if suitable facilities were provided and if they were marketed consistently (Disability Rights Task Force, 1999).

Travel intensity and frequency. Travel intensity is strongly related to existing barriers that are experienced by disabled customers in order to participate in travel and tourism activities. It refers to the percentage of the total disabled population that go on holiday. The disabled tourist represents a group that remains outside of the travel market. As a consequence, it is a group that is likely to have permanently abandoned the idea of holiday taking due to existing barriers (BMWA, 2004).

In the last few decades gradual progress has been made to remove barriers so that the transport, accommodation and attraction sectors are more accessible than they have been before. In the UK, this is partly due to the Disability Discrimination Act. Since 1995 it requires tourism suppliers to make adequate provision for disabled access. Furthermore, new buildings only gain planning permission if they provide facilities for the disabled (Stumbo and Pegg, 2005; Shaw and Coles, 2004; Shaw et al. , 2005). However, a disproportionately small number of people with disabilities participate fully in mainstream tourism (Darcy, 1998).

Findings about the travel intensity of German disabled travellers provide some important insights into these travel patterns. BMWA (2004) revealed that the travel intensity of people with disabilities is below that of the overall German population. German disabled customers have a travel intensity of 54.3 per cent for taking holidays. This is considerably below the 75.3 per cent of the overall German population. Based on these findings it can be reasoned that many disabled tourists effectively stay outside of travel experiences due to perceived or real accessibility barriers. Respondents of the sample of the BMWA (2004) survey explained their absence of holiday taking by a lack of accessible products and services available.

Travel frequency investigates how often disabled travellers undertake journeys for holiday purposes. On average, persons with disabilities take an average of 1.3 holidays and 2.3 short breaks a year (BMWA, 2004), however the travel seasonality of disabled tourists differ from the able bodied tourist. Once an appropriate destination has been selected by the disabled traveller, they tend to ensure that they make use of the low season for their holiday, subsequently avoiding crowded places.

PAGE $206 \mid$ JOURNAL OF TOURISM FUTURES $\mid$ VOL. 1 NO. 32015 
Ageing population. An ageing population is a world-wide phenomenon. In 1999, 10 per cent of the World's population were aged 60 years or more, a figure which is expected to grow to 29 per cent in 2050 (Tinker, 2002). It is forecast that 35 per cent of the population in developed countries will be at least 60 years old in 2050 (Tinker, 2002). With an ageing population, where a large proportion has grown up travelling, tour operators may soon find their core customer evolving with this demographic change. There is a direct link between age and disability. A person is 14 times more likely to have a disability by the time they reach 65 years old than a four-year old (Dwyer and Darcy, 2008). What's more, this demographic containing a greater proportion of seniors, unlike past generations, is seeking an active and adventurous experience for their post work lives, and tourism is seen as an important component of their quest for life experiences (Luiza, 2010). Currently there is no comprehensive solution that provides people with disabilities with the same travelling opportunities that an able bodied person has.

\section{Current issues preventing accessibility - the supply side}

There is a current need in the market for modification of destination facilities, reliable online information and relevant policies that allow and encourage the disabled population to travel as an able bodied tourist can.

Facility design. The United Nations (1990) Standard Rules on the Equalisation of Opportunities states that in all societies there are still obstacles preventing persons with disabilities from exercising their rights and freedoms. These obstacles make it difficult for them to participate fully in the activities of their societies and it is the responsibility of states to take appropriate action to remove such obstacles. Facility design is considered to be the main obstacle preventing disabled tourists from taking holidays. When people with impairments travel, special requirements exist. Physical access is one of the most important and influential supply side issues facing the tourism market.

Darcy (1998) argues facility design can be split into three dimensions:

1. physical access, which involves people with physical impairments using wheelchairs or walking aids;

2. sensory access, for example tactile markings, signs and labels, hearing augmentation systems and audio cues for lifts and lights; and

3. communication access, which involves people that have difficulties with written word and speech.

Research on accessible accommodation (Darcy and Pegg, 2011) concluded that the accessible rooms of the hotels met access provisions, however not all areas of the hotels were accessible. Infrastructure with easy access as well as a variety of accessible products must be provided by tourism suppliers to fulfil the criteria of accessible tourism. An existing problem in facility design is the tendency for accommodation designers to provide the minimum features for an accessible room, instead of designing the best possible disabled room. On top of this, only a fraction of the total number of rooms in a hotel are accessible.

Information. A second obstacle to accessible travel is the distribution of unreliable tourism information. Tourists with disability requirements search for information that suits their relevant needs, thus the higher the accessibility requirement the more detailed the information required is. Many mainstream travel publications, including hotel directories, use the international wheelchair symbol to indicate accommodation that claims to offer facilities for disabled guests, but more specific details of these facilities are rarely stated (European Commission, 1996). The lack of available information has forced disabled tourists to abandon the practice of taking holidays or seek alternative leisure solutions (Waschke, 2004).

Attitudes. Attitudinal issues add a third dimension to problems facing disabled tourists and the way disability is perceived. When looking to the social model (Buhalis et al., 2005) of disability for an explanation, one begins to understand disability is normal and it is actually the environment and societal systems that create accessibility barriers. If this belief was exemplified by major travel 
and leisure companies, holiday environments and systems would be designed in a way that reflected the social model to disability. This is a view supported by 97 per cent of European citizens, who state that the integration of people with disabilities into society could be improved (Eurobarometer, 2001). A common complaint about tourism and travel staff is the negative, demeaning or condescending staff attitudes (Burnett and Bender Baker, 2001), exemplifying that cultures of many major travel and leisure companies fail to support the social model of disability. Ensuring greater customer satisfaction in this regard will involve a better focus on staff training (Stumbo and Pegg, 2005).

It has been made apparent people with disabilities face a number of barriers that prevent them from going on holiday. These include environmental, interactive and intrinsic barriers (Yau et al., 2004). If major travel and leisure companies break down the facility design, information and attitudinal barriers, certain intrinsic barriers such as perceived and psychological obstacles may also begin to be broken down.

\section{Devising a comprehensive solution}

Previous literature on accessible tourism has mainly focused on defining relevant terminology (Darcy, 1998; Aitchison, 2003; Buhalis et al., 2005; Darcy and Buhalis, 2011) and assessing how the disabled population is made up, alongside how it has evolved. A subject covered in less detail is the involvement of major travel and leisure companies and how managers of these organisations perceive this new market segment.

Major travel and leisure company involvement. It is essential for the travel and tourism industry to create and implement strategies to remove attitudinal, social, physical and informational barriers. Major travel and leisure companies will have a big influence in delivering these strategic initiatives, as ultimately it is the global players' distribution channels that best supply the market. Major travel and leisure companies maintain the characteristics to provide a comprehensive or "one stop shop" solution, particularly those with a global presence and local expertise in destinations handled.

Legislation. On 24 July 2009 Barack Obama, signed the UN Convention on the Rights of People with Disabilities. In doing so, the USA became one of many signatory countries to the agreement which seeks to ensure the rights of people with disabilities. Article 30 of the Convention proclaims the right to access all areas of cultural life, including that of tourism, thus putting tour operators on notice to change their operations in order to guarantee access to tourism goods and services for people with disabilities.

Certain policy implementation such as the legislation designed to make it compulsory for tourism suppliers to create an environment that is accessible to disabled people increases the economic gain for the tourism industry by increasing the purchasing power of the disabled population (Buhalis et al., 2005). However researchers have noted that despite the large numbers of people with disabilities living independently, their growing financial wealth and their desire to travel, this segment continues to be largely ignored by the tourism industry worldwide (Darcy, 1998). Increasing the economic gain by implementing legislation into the supply side of the tourism industry is one of a twofold effect of policy setting (Upchurch and Won, 1996), the second being the reference to a fundamental civil right for all citizens, and an enriched life of disabled and elderly people.

It is no new notion that there must be a reaction in the industry resulting in the gap between limited supply and high demand reducing; in 1983 Mills noted that the provisions for the disabled in any type of holiday situation can no longer be regarded as an optional extra. The tourism industry must ensure that tourism policies and initiatives are responsive to current and future trends and issues (Dwyer et al., 2009), allowing the supply side of the accessibility market to meet the needs and demands of the disabled consumer.

\section{Data collection methods}

Accessible tourism has received increasing attention due to a hypothetical increase in demand for this type of vacation, and subsequently suggests it is an attractive market for major travel 
and leisure companies to be active in. This study differs from those previously undertaken in that the population for this study is major travel and leisure companies. This was considered critical, as it is believed travel and leisure companies provide the best insight into accessible tourism provision.

\section{Market value analysis}

The accessible tourism market is an attractive segment for travel and leisure companies, however the tourism industry has made limited progress so far in providing the market with accessible products. In order to measure the value and potential of the demand side of accessible tourism in Europe, the exploration of travel patterns of disabled tourists, in particular spend per head per holiday (Puhretmair, 2004) was examined. Sources used to collect figures of disability populations, average spend per disabled tourist and GDP/Capita included international bodies such as Eurostat, Euromonitor, Eurobarometer, The World Bank and Census Bureau's, alongside National Tourism Authorities.

Absolute figures of the prevalence of disability are difficult to estimate due to a lack of standardised data and comprehensiveness (Buhalis et al., 2005) and after reviewing statistics from previous research it becomes clear that estimates for disability volume vary from source to source (Dupré and Karjalainen, 2003; National Disability Authority, 2003; Puhretmair, 2004). However by focusing on three variables; a specific disability type, selected age range and average travel spend of tourists within this demographic, while using reliable sources for such data, it becomes possible to attempt to quantify the economic value potential of the accessible tourism industry. Using the elderly (>65 years) demographic when estimating market value, an overview of the total accessible tourism market value is proposed. The last paper to conduct a comprehensive analysis of potential accessible tourism market value was the "One Stop Shop for Accessible Tourism in Europe" (Buhalis et al., 2005). The data used in Buhalis et al. (2005) paper is used in this research as a launch pad in forecasting market value up until 2025.

Market value analysis assumptions. A number of assumptions are made in the market value forecast:

- Deloitte estimate only 70 per cent of the disabled population demanding accessibility can travel due to physical and economic capabilities (Van Horn, 2002).

- Deloitte also state a multiplier effect of 0.5-2.0 has to be taken into consideration when calculating market value (Van Horn, 2002). This is due to the fact a disabled tourist will often take a carer, family member or friend on holiday with them.

- The elderly population ( $>65$ years) makes up 64.8 per cent of the total disabled population requiring accessibility (Buhalis et al., 2005).

- Travel spend per head per holiday, and the growth of this from 2005 to 2025, is calculated for each European country by applying a factor of 1 to the German data (2005-2025), then determining the factor for each country based on its GDP per Capita to calculate the average travel spend for each of the other European countries included in this research. The proportionate change in GDP per Capita from 2005 to 2025 is then used to calculate the growth in average travel spend per head per holiday.

\section{Semi structured interviews}

Interviews were carried out with employees of major travel and leisure companies in managerial positions. The interviews assessed the activity of these companies in the accessible tourism market alongside managers' perceptions of the attractiveness of the accessible tourism industry.

Sample. In-depth semi structure interviews were undertaken with the following types of manager: one CEO, one CFO, one director, one non-exec, two commercial directors and six strategy managers. Each interview lasted between $30 \mathrm{~min}$ and $1 \mathrm{~h} 15 \mathrm{~min}$. 


\section{Findings and discussion}

This section is split into two parts:

- Part 1 presents the value forecast for the accessible tourism industry from 2005 to 2025.

- Part 2 documents the managerial perceptions of the accessible tourism market. A summary of the main findings and representative quotes can be seen in Table II. In addition to the semi-structured interviews, a short survey was conducted to provide a quantitative representation of these managerial perceptions. The findings of this survey can be seen in "4.3. Survey Findings".

\section{Market analysis}

Focusing on the elderly population demographic allowed for an overall prediction of the accessible tourism market value, if provision of accessible products/services was sufficient (see Table I for an overview of this forecast, Table Al (the Appendix) for the complete data and Table All (the Appendix) for a breakdown of disability type).

Based on the assumption the disabled tourist travels alone, the total market value is expected to increase by 65 per cent (2.6 per cent CAGR) from 2005 to 2025 from $€ 53.5$ billion to €88.6 billion. If the disabled tourist travels with a companion, Deloitte state a multiplier effect of 0.5-2.0 people must be taken into consideration, resulting in a market value of $€ 80.3$ billion in 2005 growing to $€ 132.8$ billion in 2025 (if using the 0.5 multiplier effect. See Table I. for a potential market value if 2.0 people travel with the disabled tourist).

Based on these findings and according to The World Bank (2014) data the accessible tourism market in Europe (focusing on the countries included in this research and assuming the disabled tourist travels alone) would have accounted for 16.9 per cent of total European tourism receipts in 2005 had a comprehensive solution been in place and allowed for barrier free tourism. (This figure is calculated using the USD/EUR exchange rate on the 31 January 2005. If the 31 January 2014 rate is used this figure equals 17.4 per cent).

Table I Overview of the accessible tourism market value in Europe (2005-2025)

Year

2005

2025

Elderly population (> 65 years) ${ }^{a}$

$80,222,000$

$103,535,000$

29

Total demand for accessibility (including all disability types) $)^{\mathrm{b}}$

$70 \%$ that have the economical and physical capability to travel ${ }^{\mathrm{C}}$

Average spend/head/holiday ${ }^{\mathrm{d}}$

$123,761,185$

$159,726,936$

29

$86,632,829$

$€ 618$

$111,808,855$

29

Potential tourism revenues ( $70 \%$ of the elderly

population that have the capability to travel multiplied

$€ 792$

by Average spend/head/holiday)

Deloitte's multiplier effect (PAX) for friends and family

who travel with the disabled tourist ${ }^{\mathrm{e}}$

Accompanying friends and family

Total market potential incl. $70 \%$ of disabled

population who have the capability to travel, plus their accompanying friends and family

$€ 53,539,088,553$

Potential tourism revenues Total market potential incl. accompanying friends and family multiplied by

Average spend/head/holiday
0.5

$43,316,415$

$129,949,244$

$259,898,488$

$167,713,283$

$335,426,566$

29

$€ 80,308,632,829 € 160,617,265,659 € 132,828,920,086 € 265,657,840,173$

0.5

29

$223,617,711$
65

$€ 88,552,613,391$

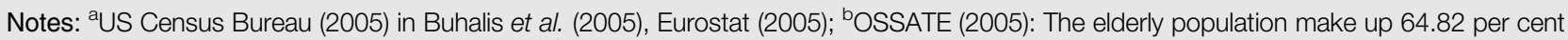
of the total disabled population; 'OSSATE (2005); 'BMWA (2004), Buhalis et al. (2005) and Euromonitor (2013): This average spend per head per holiday figure is in line with other sources, such as OSSATTE (2005) who calculated $€ 620$; ${ }^{\vee}$ an Horn (2002). Deloitte state that the disabled tourist often takes a carer, friend or family member on holiday and this needs to be included in the total market value calculation 


\section{Emergent themes and representative quotes}

There are five consistent themes within the interview data. A number of these themes link to previous accessible tourism literature, however there are also some unique findings (such as "partnerships" and "cost of investment"). A summary of emergent themes and representative quotes can be seen in Table II and accompany major considerations for each of the following themes:

- Partnerships.

- Awareness.

- Cost of investment.

- Complexity.

- Legislation and compliance.

Partnerships. The predominant finding from the interviews was barriers involving traditional suppliers and inaccessible infrastructure prevent partnerships required to develop a comprehensive solution for barrier free tourism.

In a recent tourism summit, André Vallerand, Special Advisor to the Secretary of the World Tourism Organization (UNWTO), President of the World Centre of Excellence for Destinations, and co-chair of the Summit argued that:

The development of universal accessibility of infrastructures, tourism services, and transport services cannot be done without a global partnership: we must share our knowledge and best practices for dissemination, and convince our partners that sustainable development must be inclusive (Destinations Pour Tous, 2014).

This is a view shared by 50 per cent of the interviewees in this research. For tour operators, the difficulty in offering accessible products to disabled tourists is increased if suppliers fail to

Table II Emergent themes and representative quotes

\begin{tabular}{|c|c|}
\hline Emergent theme & itative quote \\
\hline Partne & $\begin{array}{l}\text { "I think it is important to be early on in the process, we often come to a facility that is already built, and then of course if it is } \\
\text { not built to the spec that we want, we cannot rebuild it to the accessibility we would like, one obstacle is different } \\
\text { standards between different suppliers" } \\
\text { "[...] we offer accessible transportation from the airport to the hotel, we've had some challenges in some places to find } \\
\text { the right supplier for that" } \\
\text { "[...] if the demand is there we have the ability to go to our partners and say 'listen, there is a part of the market that you } \\
\text { guys aren't serving and we have access to that demand', if we genuinely do have access to that demand, 'so if you can } \\
\text { develop a product that we can sell, there is an opportunity here" }\end{array}$ \\
\hline Awareness & $\begin{array}{l}\text { "[...] I was quite stunned when I saw the valuation of the market. Quite frankly I wouldn't know what figure to put, I would } \\
\text { never have anticipated it exceeding } € 70 \text { billion and } 10 \text { years on it has obviously grown" } \\
\text { "[...] To be honest the figure sounds very high, but it's also a matter of definition, what do you mean by } \\
\text { accessible tourism?" } \\
\text { "[...] if you create awareness then people will go there, I just don't think [accessible tourism] has got any awareness. } \\
\text { I haven't seen a report from anybody on this" } \\
\text { "[...] I actually think there will be a lot of people in travel companies who won't even be thinking about this segment of the } \\
\text { market, or even understand that there is a customer who is willing to travel but needs the relevant product" }\end{array}$ \\
\hline Cost of investment & $\begin{array}{l}\text { "[...] the reward, effort ratio is not as attractive as other customer segments" } \\
\text { "[...] to deliver the right product, you are going to have to invest, in something that your core customer doesn't require } \\
\text { and you are not going to be able to charge a premium for it" } \\
\text { "[...] there will probably be a thought process that this is going to cost us too much" }\end{array}$ \\
\hline Complexity & $\begin{array}{l}\text { "[...] it is difficult if the customer does not mention that they have a disability, which makes it difficult to cater for } \\
\text { their needs" } \\
\text { "[...] we are a pure online business so can you fulfil this type of transaction online? Or is it too bespoke for an online query } \\
\text { or reservation?" }\end{array}$ \\
\hline $\begin{array}{l}\text { Legislation and } \\
\text { compliance }\end{array}$ & $\begin{array}{l}\text { "Even within the EU there is a huge disparity in what the destination country deems to be equal opportunity and many } \\
\text { countries are culturally well behind the UK in its treatment of persons with reduced mobility." } \\
\text { "[...] there is no standard for assessing what is for example an adapted room" }\end{array}$ \\
\hline
\end{tabular}


develop accessible products themselves. This issue is exaggerated for intermediaries like accommodation wholesalers. For pure online businesses, a lack of available products force a restriction on the ability to service it online, particularly when considering the "on request" nature of accessible tourism products.

Until a common accessible tourism product, preferably a universally designed product (e.g. a completely accessible holiday resort) is established in the tourism industry, the majority of stakeholders will be prevented from cost effectively marketing products and services to the disabled tourist segment.

Awareness. There is still a clear lack of awareness in the tourism industry of accessible travel and the extent of the demand for accessibility, although it is well understood that there is a relevant segment of the market which is poorly served. The lack of awareness relates to the extent of demand, but to some, also to the definition of accessible tourism. In all, 25 per cent of interviewees stated a lack of awareness was a major obstacle when devising initiatives to sell accessible products. Up to 67 per cent of interviewees were unaware of the potential value of the accessible tourism market, stating the forecast amount by Buhalis et al. (2005)was higher than they expected.

It is evident the cruise industry is more aware than other travel and leisure segments, due to the fact that their core customer is slightly older, and predominantly from the USA, where accessible products have been more commonplace for a longer time. For other travel and leisure companies, it is argued that the slow reaction to accessible tourism demand is due to the fact their core customer is positioned outside of the disabled demographic. The consequences of this reasoning could be severe. With the baby boomers now swelling the ranks of the $65+$ population, in 2004 the UK baby boomers held 80 per cent of the UK's wealth (Walker, 2004) and over 50 per cent of discretionary spending is controlled by the elderly (Janger, 2011).

When discussing the reasons behind an increasing awareness and focus on accessible tourism, the majority of managers looked to corporate social responsibility (CSR) and the fact that CSR is the "flavour of the month" or "to be seen as socially responsible is en vogue." Combining this with the notion that the disabled tourist has greater buying power than before and a louder voice, the tourism industry is "better placed than it has ever been" in terms of offering disable tourists accessible products and services.

It is evident varying levels of awareness exist, and the majority of managers are not only unaware of accessible tourism as a concept or definition, but they are also largely unaware of what features contribute to an accessible product. Two previous studies looking at perceptions of accommodation managers concluded that many managers did not even understand the access features of their hotel rooms, let alone provide any level of detailed information beyond whether an establishment had a disabled room (Ozturk et al., 2008). It has also been argued tour operators are largely ignorant of the specific needs of people with disabilities, which leads to overt or subtle discrimination (McKercher et al., 2003).

Travel retail has proven to be an inhibitor rather than a facilitator and there is an immediate need for a stepping up of research in the field (Blichfeldt and Nicolaisen, 2011) and discussion and debate on the needs and demands of the disabled population to become active tourists (Pagán, 2009).

Cost of investment. Common across all the interviewees' perceptions was the prediction that companies in the travel and leisure industry were refraining from entering the accessible tourism market due to the perception that the effort to reward ratio is not as attractive as other consumer segments. A key perception is that to deliver accessible products, for example, tour excursions (which may require transfers using accessible transport, appropriately trained tour guides and suitable equipment), investment will be high, and unlike other tourism segments a premium for accessible products cannot be charged. However, as one manager suggested, while pressure on top line growth exists across the industry, and more travel and leisure companies fight for market share, an increasing amount of businesses will be looking to new areas, such as the accessible tourism market, for a first mover advantage. 
An issue in the journal Current Issues in Tourism (2011) analysed topics relating to accessible tourism and found that the most important barrier to participation is affordability (Bélanger and Jolin, 2011; Diekmann and McCabe, 2011; Minnaert et al., 2011). In addition, disabled tourists incur additional costs relating directly to their disability (e.g. insurance, medical expenses, equipment, personal assistance support). All these circumstances account for the lack of participation in tourism activities and reduce the development of the accessible tourism market segment. It is suggested tourism products aimed at the disabled tourist are too bespoke or too costly, however it is also argued by authors of previous accessible tourism literature (see Buhalis et al., 2005; Darcy and Buhalis, 2011; Darcy and Dickson, 2009) that if suppliers facilitate the development of "universal design" tourism products, costs to travel and leisure companies and subsequently the market as a whole will be reduced.

It is vital major operators in the travel and leisure industry properly market their accessible products and services (Upchurch and Won, 1996) in order to facilitate return on investment. It is apparent operators do this for other market segments, but have not done it for the disabled tourist. BMWA (2004) concluded that many tourists have abandoned the idea of taking a holiday due to existing barriers. This conclusion would not favour one manager's belief, that accessible tourism products should not be marketed separately from "normal" tourism products, due to discriminatory reasons. However, marketing of accessible products in the future may be vital in making customers aware of accessible products and attempting to turn unhappy and frustrated customers who require improved accessibility, into loyal customers.

By increasing awareness and marketing efforts surrounding accessible products, travel and leisure companies may answer a number of recurring questions, such as whether the demand for accessible tourism exists, how access to that demand is achieved, and whether accessible products can be marketed efficiently?

\section{Legislation and compliance}

Without doubt the biggest threat faced by the hotel industry is its very ignorance of its obligations under the legislation (O'Neill and Ali Knight, 2000, p. 171).

Compliance with legislation in the tourism industry is often not met and a lack of understanding is apparent (Upchurch and Won, 1996).

It is argued that tour operators need to be aware that they have a social responsibility for meeting the needs of people with disabilities, as well as a legislative requirement to do so. In this sense, public policy in tourism can be linked to more general social policies of disability and exclusion in order to facilitate the full integration of disabled people into the tourism industry.

The existence of a greater convergence of tourism policies across Europe and the definition of measures and tools that increase knowledge, competitiveness and sustainable development of the tourist industry are key factors in the near future for the accessible tourism market (European Disability Forum, 2001). There is a contrast between certain European countries and the standards they comply with. Certain countries such as the Nordics and the UK exemplify the advantages of construction legislation within these regions, whereas nations such as Turkey and Egypt appear to be less stringent when it comes to accessible facility design. As one manager stated; "That's not something that will change overnight", a perception which highlights an area of concern for travel and leisure companies who are experiencing difficulty in developing accessible holidays when existing facilities in destinations are largely inaccessible.

Commenting on the inconsistency of legislation across the EU, one manager stated:

Even within the EU there is a huge disparity in what the destination country deems to be equal opportunity and many countries are culturally well behind the UK in its treatment of persons with reduced mobility, thus attitudes to accessibility may be less well advanced than in the UK. This gives us a big challenge in getting properties and hoteliers not to discriminate.

Complexity. To achieve information satisfaction and fully enable access to tourism for people with disabilities, a more sophisticated understanding of different needs and appropriate sources, accessible destination experiences, and the provision of adequate accommodation is needed by 
tourism operators (Darcy, 2010). 25 per cent of interviewees stated that complexity of information relating to each disability type was a major obstacle in selling accessible products.

In addition, education relating to people with disabilities could change attitudes within the tourism industry, wherein short educational programs targeting employees of travel and leisure companies help correct existing negative attitudes towards people with disabilities (Blichfeldt and Nicolaisen, 2011).

\section{Survey Results}

Alongside the semi structured interviews, a short survey was conducted to provide a quantifiable overview of the analysis into managerial perceptions and the reasons for and against current company activity levels in the accessible tourism market (Figures 1-4).

\section{Conclusion}

It is clear from data in this paper and evidence in the wider literature that people with disabilities are being served poorly by the tourism industry.

There is a need for stakeholders to work together when devising accessible tourism solutions. Yau et al. (2004) have rightly argued, travelling with a disability is more than an access issue. Rather, it involves a series of interdependent and overlapping factors, each of which need to be fully considered. For a tourism trip to occur, the organisation of all sectors of the tourism industry is critical. This involves all stages of travel, from anticipation and planning; travelling to the destination, on-site experience, to return travel.

\section{Figure 1 The market value of the accessible tourism industry was estimated to be} worth over €70bn in 2005

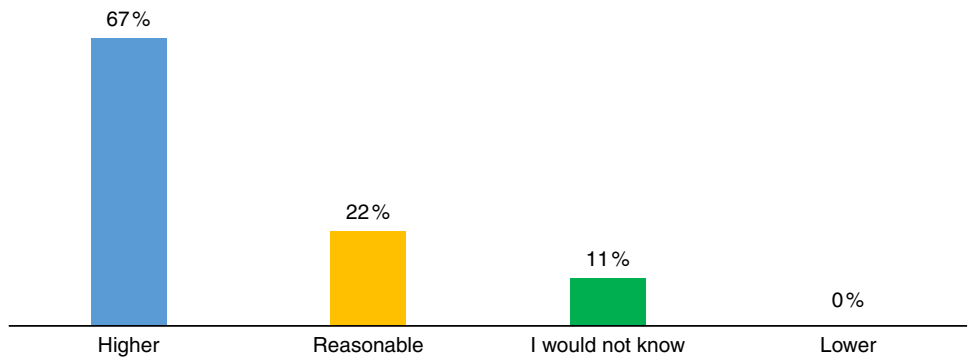

Note: How does this figure relate to your own perception of the accessible tourism market value? Is it

Source: OSSATE (2005)

\section{Figure 2 Does your company currently sell accessible tourism products to disabled} tourists?

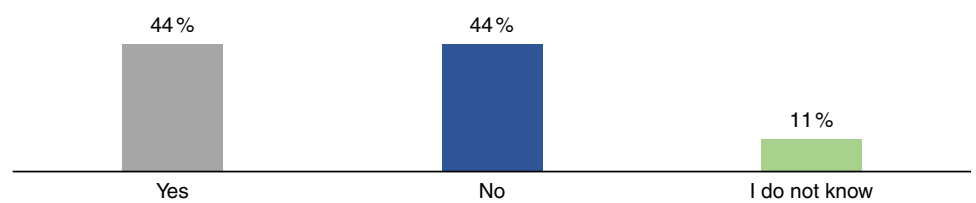




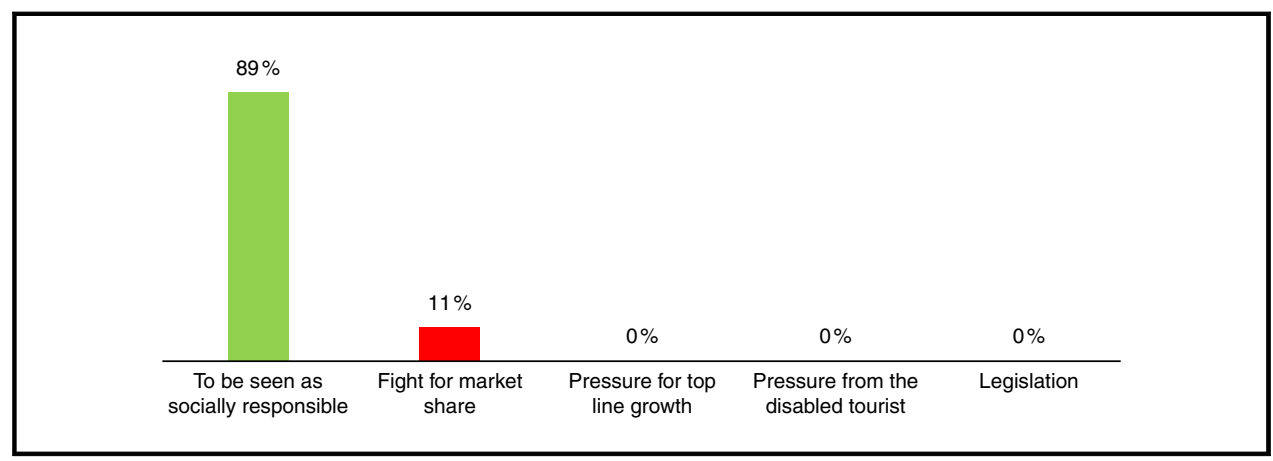

Figure 4 If your company does provide accessible products to disabled tourists, please select the following obstacles you may have faced when devising initiatives to sell these products? (please tick as many relevant choices)

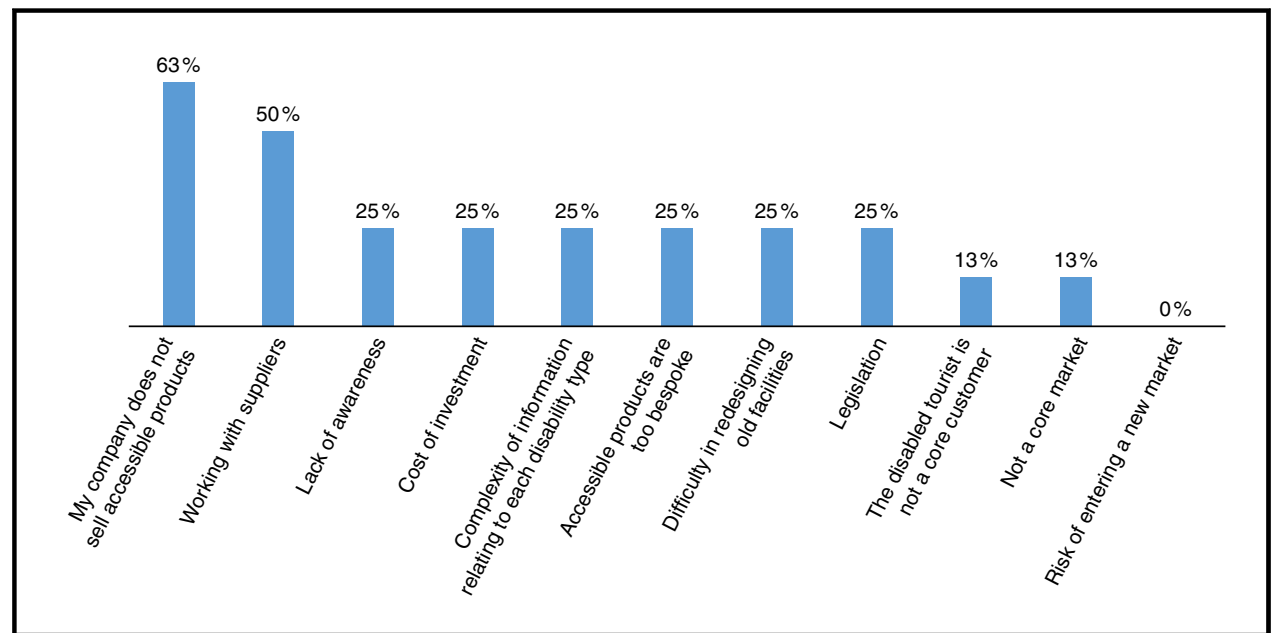

Before accessible tourism products are offered to the market, accessibility must be conceived as a social right (ENAT, 2007). The tourism industry has been reactive in responding to the need to serve an evolving core customer. With demographic changes occurring all over the world, the prevalence of disability is increasing and the demand for accessible products and services is following suit.

The tourism industry will benefit from gathering further data on accessibility, exemplified in the wider literature and in interview data conducted for this research study. Focus groups involving a variety of stakeholders in the accessible tourism industry, such as disabled tourists, accommodation suppliers, tour operators, government and airline managers, will allow for greater insight and a sharing of best practice. As the fight for market share continues, new growth opportunities in the tourism industry are constantly being analysed. As soon as major travel and leisure companies are fully aware of the sheer demand for accessible tourism, and how they can access this demand, there is no doubt the industry will develop more effective solutions to serve the disabled tourist. Increased awareness will result from additional research, as well as an increasing number of companies servicing disabled tourists and subsequently proving the market. However, while travel and leisure companies are always looking for the next growth opportunity, it is becoming increasingly apparent that it will take a major player to make a distinct first move, until the accessible tourism market gains any real pace. For this to happen a 
combination of increased awareness, education, legislation, partnerships and the resolve to invest in universal design needs to be apparent. This will help to provide a launch pad for companies in the travel and leisure industry to take the leap and benefit from the attractive accessible tourism industry.

\section{Critical reflection of this research study}

As one director correctly stated: "This interview is of itself being discriminatory in attempting to define 'accessible tourism' as something different to normal tourism." On this basis, a high proportion of the literature surrounding accessible tourism should also be deemed inequitable. It seems until everyone has the same opportunity to travel, regardless of access requirements, this will continue to be an issue. The call for universal design (of hotel rooms, restaurants, airplanes, cruise ships etc.), seems to be an ambitious solution, but gives an insight into just how drastically the environment and society we live in needs to change, before disability is considered "normal".

\section{Investment return trade-off, an area for further research}

Based on the emergent theme of "cost of investment" in this paper, an area for future research may be a more detailed assessment on the return on investment and the cost of operating in the accessible tourism market. This would assess the interchange of opening up a new market segment and the subsequent creation of demand, alongside the potentially significant investments required to offer barrier free tourism.

\section{References}

Aitchison, C. (2003), "From leisure and disability to disability leisure: developing data, definitions and discourses", Disability and Society, Vol. 18 No. 7, pp. 955-69.

Bélanger, C.É. and Jolin, L. (2011), "The international organisation of social tourism (ISTO) working towards a right to holidays and tourism for all”, Current Issues in Tourism, Vol. 14 No. 5, pp. 475-82.

Blichfeldt, B.S. and Nicolaisen, J. (2011), "Disabled travel: not easy, but doable", Current Issues in Tourism, Vol. 14 No. 1, pp. 79-102.

BMWA (2004), "Federal Ministry of Economic and Labour - economic impulses of accessible tourism for all", Report, Bundesministerium für Wirtschaft und Arbeit, Berlin, December 2003.

Brault, M.W., Hootman, J., Helmick, C.G., Theis, K.A. and Armour, B.S. (2009), "Prevalence and most common causes of disability among adults-United States, 2005", Morbidity and Mortality Weekly Report, Vol. 58 No. 16, pp. 421-6.

Brouillette, D.C., Hotchkiss, R. and Saleh, L. (1995), "Overcoming obstacles to the integration of disabled people", UNESCO report, March, available at: www.daa.org.uk/uploads/pdf/Overcoming\%20Obstacles.pdf (accessed 20 September 2015).

Buhalis, D., Eichhorn, V., Michopoulou, E. and Miller, G. (2005), "Accessibility market and stakeholder analysis", OSSATE project, University of Surrey, Guildford.

Burnett, J.J. and Bender Baker, H. (2001), "Aassessing the travel-related behaviours of the mobility-disabled consumer", Journal of Travel Research, Vol. 40 No. 1, p. 411.

Darcy, S. (1998), "People with a disability and tourism bibliography", Bibliography No.7, available at: www. business.uts.edu.au/lst/downloads.07_Disabiliy_Tourism.pdf (accessed 1 November 2013).

Darcy, S. (2010), "Inherent complexity: disability, accessible tourism and accommodation information preferences", Tourism Management, Vol. 31 No. 6, pp. 816-26.

Darcy, S. and Dickson, T. (2009), "A whole-of-life approach to tourism: the case for accessible tourism experiences”, Journal of Hospitality and Tourism Management, Vol. 16 No. 1, pp. 32-44.

Darcy, S. and Pegg, S. (2011), "Towards strategic intent: perceptions of disability service provision amongst hotel accommodation managers", International Journal of Hospitality Management, Vol. 30 No. 2 , pp. 468-76.

Darcy, S. and Buhalis, D. (2011), "Introduction: from disabled tourists to accessible tourism", Accessible Tourism: Concepts and Issues, pp. 1-20. 
Darcy, S., Cameron, B., Pegg, S. and Packer, T. (2008a), "Technical report 90042: developing business cases for accessible tourism”, STCRC Technical Report, available at www.crctourism.com.au/BookShop/ BookDetail.aspx?d=582 (accessed 1 November 2013).

Darcy, S., Cameron, B., Dwyer, L., Taylor, T., Wong, E. and Thomson, A. (2008b), "Technical report 90064: visitor accessibility in urban centers", Sydney, October, available at: www.crctourism.com.au/BookShop/ BookDetail.aspx?d=626 (accessed 1 November 2013).

Department for Culture, Media and Sport (2010), "Accessible tourism: making it work for your business", available at: www.culture.gov.uk (accessed 24 November 2013).

Destinations Pour Tous (2014), "Tourism, culture and transportation, a common strategy at the international level”, available at: www.accessibletourism.org/resources/press-release-save-the-date_en-2.pdf (accessed 10 January 2014).

Diekmann, A. and McCabe, S. (2011), "Systems of social tourism in the European Union: a critical review", Current Issues in Tourism, Vol. 14 No. 5, pp. 417-30.

Disability Rights Task Force (1999), "From exclusion to inclusion: final report of the disability rights task force", available at: www.disability.gov.uk/drtt/full_report/\#ad_6 (accessed 15 January 2014).

Dupré, D. and Karjalainen, A. (2003), "Employment of disabled people in Europe in 2002", Statistics in Focus, Theme, pp. 3-26.

Dwyer, L. and Darcy, S. (2008), "Chapter 4-economic contribution of disability to tourism in Australia", Technical Report, 90040, pp. 15-21.

Dwyer, L., Edwards, D., Mistilis, N., Roman, C. and Scott, N. (2009), "Destination and enterprise management for a tourism future", Tourism Management, Vol. 30 No. 1, pp. 63-74.

Ells, C. (2001), "Lessons about autonomy from the experience of disability", Social Theory and Practice, Vol. 27 No. 4, pp. 599-615.

Eurobarometer (2001), "Attitudes of Europeans to disability", European Commission, Brussels, available at: http://europa.eu.int/comm/public_opinion/archives/eb/ebs_149_en.pdf (accessed 30 April 2014).

Euromonitor (2013), "Tourism flows outbound in Germany", available at: www.euromonitor.com/tourismflows-outbound-in-germany/report (accessed 24 March 2014).

European Commission Tourism Unit (1996), Making Europe Accessible for Tourists with Disabilities: Handbook for the Tourism Industry, Office for Official Publications of the European Communities, Luxembourg.

European Disability Forum (2001), EDF Position Paper on Tourism: Framing the Future of European Tourism, Doc. EDF 01/13 EN, EDF, Brussels.

European Network for Accessible Tourism (2007), Rights of Tourist with Disabilities in the European Union Framework, Fundacion ONCE, Athens.

Eurostat (2005), "Population and social conditions: percentual distribution of types of disability by sex and age group", available at: http://epp.eurostat.cec.eu.int (accessed 20 September 2015).

Fost, D. (1998), "The fun factor: marketing recreation to the disabled”, American Demographics, Vol. 20 No. 2, pp. 54-8.

Horgan-Jones, M. and Ringaert, L. (2004), "Accessible tourism in Manitoba”, available at: www.ttra.com/pub/ uploads/AccessibleTourismlnManitoba.htm (accessed 30 November 2014).

Hsu, C. and Powers, T. (2002), Marketing Hospitality, John Wiley and Sons, New York, NY.

Janger, M. (2011), "Baby boomers: the new disability market", available at: www.brandchannel.com/ features_effect.asp?pf_id=534 (accessed 12 December 2014).

Luiza, S.M. (2010), "Accessible tourism - the ignored opportunity", Annals of Faculty of Economics, Vol. 1 No. 2, pp. 1154-7.

McKercher, B., Packer, T., Yau, M.K. and Lam, P. (2003), "Travel agents as facilitators or inhibitors of travel: perceptions of people with disabilities”, Tourism Management, Vol. 24 No. 4, pp. 465-74.

Miller, G. and Kirk, E. (2002), "The Disability Discrimination Act: time for a stick?", Journal of Sustainable Tourism, Vol. 10 No. 1, pp. 82-8.

Minnaert, L., Maitland, R. and Miller, G. (2011), "What is social tourism?", Current Issues in Tourism, Vol. 14 No. 5, pp. 403-14. 
National Disability Authority (2003), Accessibility and Tourism. Tourism Policy Review Group, available at: www.nda.ie/ (accessed 20 September 2015).

O'Neill, M. and Ali Knight, J. (2000), "Disability tourism dollars in Western Australia hotels", FlU Hospitality Review, Vol. 18 No. 2, pp. 72-88.

OSSATE (2005), "One-stop-shop for accessible tourism annual report", available at: www.ossate.org/docs/ OSSATE_D1.3_Annual_Public_Report_2005_public.pdf (accessed 20 September 2015).

Ozturk, Y., Yayli, A. and Yesiltas, M. (2008), "Is the Turkish tourism industry ready for a disabled customer's market?: the views of hotel and travel agency managers", Tourism Management, Vol. 29 No. 2, pp. 382-9.

Pagán, R. (2009), "Self-employment among people with disabilities: evidence for Europe", Disability \& Society, Vol. 24 No. 2, pp. 217-29.

Prager, J.H. (1999), "People with disabilities are next consumer niche", Wall Street Journal, Vol. 15, pp. B1, 2.

Puhretmair, F. (2004), It's Time to Make eTourism Accessible, ICCHP, Paris, pp. 272-9.

Rosenberg, D., Bombardier, C., Hoffman, J. and Belza, B. (2011), "Physical activity among persons ageing with mobility disabilities: shaping a research agenda", Journal of Ageing Research, Vol. 2011, pp. 1-16, Article ID 708510.

Shaw, G. and Coles, T. (2004), "Disability, holiday making and the tourism industry in the UK: a preliminary survey", Tourism Management, Vol. 25 No. 3, pp. 397-403.

Shaw, G., Veitch, C. and Coles, T.I.M. (2005), "Access, disability, and tourism: changing responses in the United Kingdom”, Tourism Review International, Vol. 8 No. 3, pp. 167-76.

Stumbo, N. and Pegg, S. (2005), "Travellers and tourists with disabilities: a matter of priorities and loyalties", Tourism Review International, Vol. 8 No. 3, pp. 195-209.

The World Bank (2014), "International tourism receipts", available at: http://data.worldbank.org/indicator/ST. INT.RCPT.CD (accessed 13 April 2014).

Tinker, A. (2002), "The social implications of an ageing population”, Mechanisms of Ageing and Development, Vol. 123 No. 7, pp. 729-35.

United Nations (1990), Disability Statistics Compendium, United Nations, New York, NY.

US Census Bureau (2005), "IDB summary demographic data”, International Database, www.census.gov/ (accessed 1 July 2014).

Upchurch, R. and Won, S. (1996), "Civic responsibility and market positioning: complying with the Americans with disabilities act”, Facilities, Vol. 14 Nos 5/6, pp. 48-56.

Van Horn, L. (2002), "Travellers with disabilities: market size and trends", available at: http://ncpedp.org/ access/isu-travel.htm (accessed 2 December 2013).

Vash, C.L. (2001), "Disability attitudes for all latitudes”, Journal of Rehabilitation, Vol. 67 No. 1, pp. 38-42.

Walker, D. (2004), "Live fast, die old", available at: http://news.bbc.co.uk/1/hi/magazine/3659996.stm (accessed 28 April 2013).

Waschke, S. (2004), "Labeling im Barrierefreien Tourismus in Deutschland - Vergleichende Analyse auf Basis Europäischer Beispiele”, thesis, Universität Lüneburg, Lüneburg.

World Health Organisation (WHO) (2012), "Disabilities", available at: www.who.int/topics/disabilities/en/ (accessed 28 January 2013).

Williams, S.J. (1999), "Is anybody there? Critical realism, chronic illness and the disability debate", Sociology of Health \& IIIness, Vol. 21 No. 6, pp. 797-819.

World Bank (2013), "International tourism receipts", available at http://data.worldbank.org/indicator/ST.INT. RCPT.CD?order=wbapi_data_value_2005+wbapi_data_value+wbapi_data_value-first\&sort=desc\&page=1 (accessed 24 March 2013).

Yau, M.K.S., McKercher, B. and Packer, T.L. (2004), "Traveling with a disability: more than an access issue", Annals of Tourism Research, Vol. 31 No. 4, pp. 946-60. 


\section{Further reading}

Ahrens, T. and Chapman, C.S. (2006), "Doing qualitative field research in management accounting: positioning data to contribute to theory", Accounting, Organizations and Society, Vol. 31 No. 8, pp. 819-41.

Black, T.R. (1999), Doing Quantitative Research in the Social Sciences: An Integrated Approach to Research Design, Measurement and Statistics, Sage, Guildford.

Botterill, D. and Platenkamp, V. (2012), Key Concepts in Tourism Research, Sage, London.

Braun, V. and Clarke, V. (2006), "Using thematic analysis in psychology”, Qualitative Research in Psychology, Vol. 3 No. 2, pp. 77-101.

Bryman, A. (2001), Social Research Methods, Oxford University Press, Oxford.

Bryman, A. (2008), Social Research Methods, 3rd ed., Oxford University, Oxford.

Chadwick, B.A., Bahr, H.M. and Albrecht, S.L. (1984), Social Science Research Methods, Prentice-Hall, Englewood Cliffs, NJ.

Corbetta, P. (2003), Social Research: Theory, Methods and Techniques, Sage Publications, Bologna.

Creswell, J.W. (2003), Research Design: Qualitative, Quantitative, and Mixed Methods Approaches, 2nd ed., Sage, Thousand Oaks, CA.

Creswell, J.W. and Clark, V.L.P. (2007), Designing and Conducting Mixed Methods Research, Sage Publications, Thousand Oaks, CA.

Crotty, M. (1998), The Foundations of Social Research: Meaning and Perspective in the Research Process, Sage, London.

Cukier, J. (2006), Tourism Research: Policy, Planning and Prospects, Department of Geography University of Waterloo, Waterloo.

DEO (2005), "Disability definitions and related links", available at: www.doe.mass.edu/sped/definitions.html (accessed 28 April 2014).

Durkheim, E. (1983), "Pragmatism and sociology”, CUP Archive, Cambridge University Press.

Dwyer, L., Forsyth, P.J. and Dwyer, W. (2010), Tourism Economics and Policy, Vol. 3, Channel View Publications, Bristol.

Ennis, C.D. and Chen, S. (2012), "Chapter 16: interviews and focus groups", in Armour, K. and Macdonald, D. (Eds), Research Methods in Physical Education and Youth Sport, Routledge, New York, NY, pp. 217-36.

Feilzer, M.Y. (2010), "Doing mixed methods research pragmatically: implications for the rediscovery of pragmatism as a research paradigm", Journal of Mixed Methods Research, Vol. 4 No. 1, pp. 6-16.

Fielding, N. and Fielding, J.L. (1986), Linking Data, Sage Publications, Beverly Hills, CA.

Fletcher, J. and Cooper, C. (1996), "Tourism strategy planning: Szolnok county, Hungary”, Annals of Tourism Research, Vol. 23 No. 1, pp. 181-200.

Glaser, B. and Strauss, L. (1967), The Discovery of Grounded Theory: Strategies for Qualitative Research, Wiedenfeld and Nicholson, London.

Glover, P. and Prideaux, B. (2009), "Implications of population ageing for the development of tourism products and destinations", Journal of Vacation Marketing, Vol. 15 No. 1, pp. 25-37.

Gray, D. (2009), Doing Research in the Real World, Sage Publications, London.

Greene, J.C. and Caracelli, V.J. (1997), "Defining and describing the paradigm issue in mixed-method evaluation", New Directions for Evaluation, Vol. 1997 No. 74, pp. 5-17.

Hamel, G. (1996), "Strategy as revolution”, Harvard Business Review, July-August, pp. 69-71.

Hempel, C. (1950), "Problems and changes in the empiricist criterion of meaning", Revue Internationale de Philosophie, Vol. 4 No. 11, pp. 41-63.

International Macroeconomic Data Set (2005), available at: www.ers.usda.gov/data-products/internationalmacroeconomic-data-set.aspx\#.U2GXFvldVKO (accessed 3 April 2014).

Johnson, R.B. and Onwuegbuzie, A.J. (2004), "Mixed methods research: a research paradigm whose time has come”, Educational Researcher, Vol. 33 No. 7, pp. 14-26. 
Joyce, P. and Woods, A. (1997), "Essential strategic management: from modernism to pragmatism", Long Range Planning, Vol. 30 No. 1, pp. 141.

Kemeny, J.G. (1959), A Philosopher Looks at Science, Van Nostrand, Princeton, NJ, pp. 28.

King, N. and Horrocks, C. (2010), Interviews in Qualitative Research, Sage, London.

Kuhn, T. (1970), The Structure of Scientific Revolutions, 2nd ed., enlarged., University of Chicago Press, Chicago, IL.

LaPlante, M.P. and Kaye, S.H. (2013), "Mobility device use and hearing impairments among individuals and households, 1990-2010", available at: www.access-board.gov/guidelines-and-standards/transportation/ passenger-vessels/about/mobility-device-use-and-hearing-impairments-among-individuals-and-households1990-2010 (accessed 25 April 2014).

Lastrucci, C.L. (1963), The Scientific Approach: Basic Principles of the Scientific Method, Schenkman Publishing, Cambridge, MA, p. 16.

Machery, E. (2007), "Concept empiricism: a methodological critique”, Cognition, Vol. 104 No. 1, pp. 19-46.

Maxcy, S.J. (2003), "Pragmatic threads in mixed methods research in the social sciences: the search for multiple modes of inquiry and the end of the philosophy of formalism", Handbook of Mixed Methods in Social and Behavioural Research, pp. 51-89.

Maynard, M. (1994), "Methods, practice and epistemology: the debate about feminism and research", Researching Women's Lives from a Feminist Perspective, No. 10, pp. 10-26.

Miles, M.B. and Huberman, A.M. (1994), Qualitative Data Analysis: A Sourcebook, 2nd ed., Sage, Thousand Oaks, CA.

Mills, E.D. (1983), Design for Holidays and Tourism, Butterworths, London.

Modell, S. (2009), "In defence of triangulation: a critical realist approach to mixed methods research in management accounting", Management Accounting Research, Vol. 20 No. 3, pp. 208-21.

Morgan, D.L. (2007), "Paradigms lost and pragmatism regained: methodological implications of combining qualitative and quantitative methods", Journal of Mixed Methods Research, Vol. 1 No. 1, pp. 48-76.

Neumann, P. (2002), Barrierefreier Tourismus - Vom Tourismus für Menschen mit Behinderung zum Tourismus für Alle, Universität Paderborn, Paderborn.

Newman, I. and Benz, C.R. (1998), Qualitative-Quantitative Research Methodology: Exploring the Interactive Continuum, University of Illinois Press, Carbondale, IL.

Powell, T.C. (2003), "Strategy without ontology”, Strategic Management Journal, Vol. 24 No. 3, pp. 285-91.

Ruhanen, L., Mclennan, C. and Moyle, B. (2013), "Strategic issues in the Australian tourism industry: a 10-year analysis of national strategies and plans", Asia Pacific Journal of Tourism Research, Vol. 18 No. 3 pp. 220-40.

Senlin, L. (2010), "A theoretical study of dynamic fields of pragmatic forces", Foreign Language Education, No. 5 , p. 6.

Singleton, R. Jr, Straits, B. and Straits, M. (1993), Approaches to Social Research, Oxford University Press, New York, NY.

Sustainable Tourism Cooperative Research Centre (2008), "Accessible tourism: understanding an evolving aspect of Australian tourism", available at: www.gstcouncil.org/blog/881/accessible-tourism-importancesustainable-tourism-discussion/ (accessed 20 September 2015).

Tashakkori, A. and Creswell, J. (2007), "Editorial: the new era of mixed methods", Journal of Mixed Methods Research, Vol. 1 No. 1, pp. 3-7.

Tashakkori, A. and Teddlie, C. (2003), Handbook of Mixed Methods in Social and Behavioural Research, Sage, Thousand Oaks, CA.

Van Orman Quine, W. (1976), Two Dogmas of Empiricism, Springer, Berlin, pp. 41-64. 
बำ

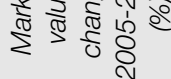

공 จ

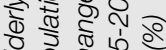

닝 ठ

ธ ญิ ฮ

要蛋

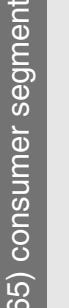

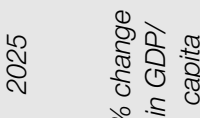

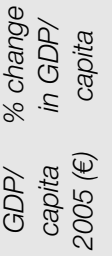

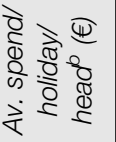

$\stackrel{2}{2} 8$

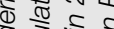

㟧

员

나 ह

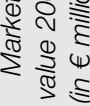

के ड्य

के $\frac{\pi}{8} \frac{\pi}{8}$

रें

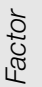

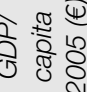

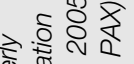

要

11
0
0
0
0

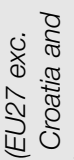

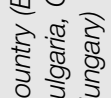

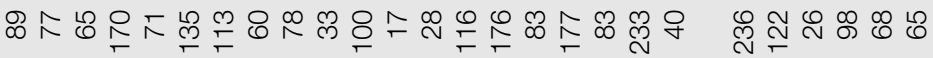

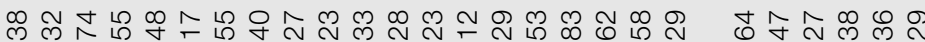

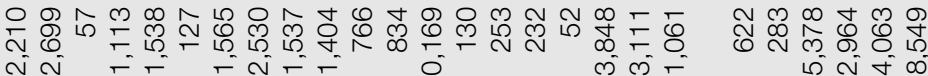

๙ิ

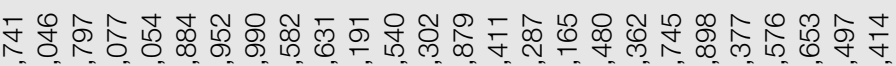

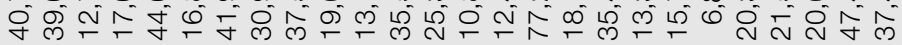

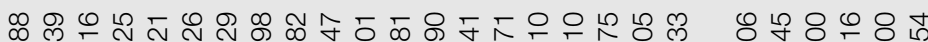
- non

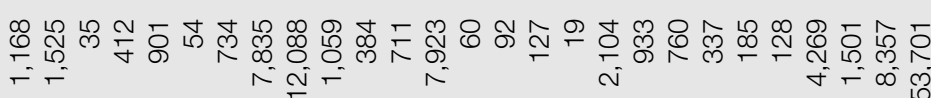

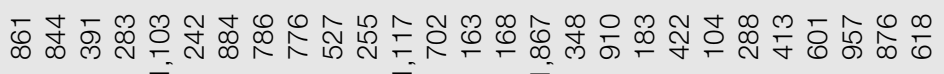

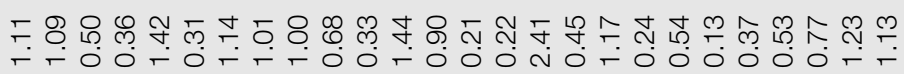

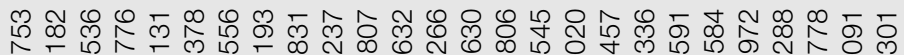

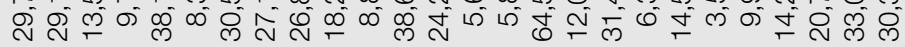

లె

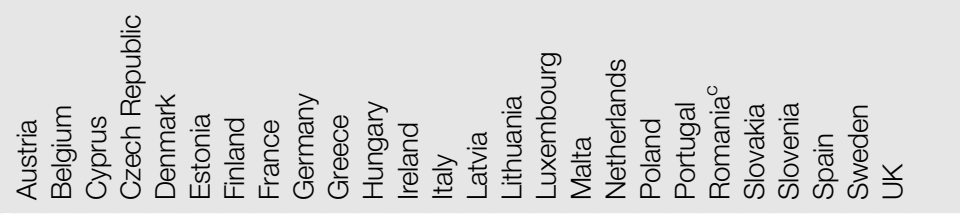

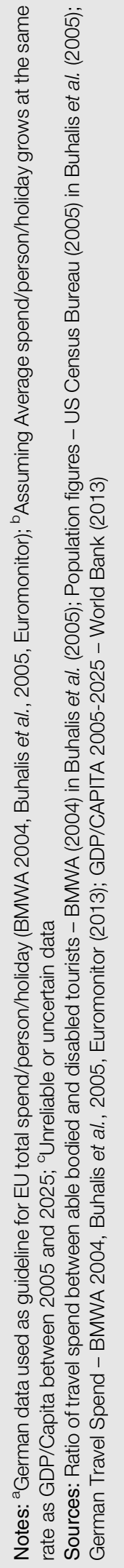


Table All Breakdown of the disabled population by disability type

Mobility impaired

16,068

1,911

Visual impaired

985

Speech impaired

246

Mental/intellectual impaired

4,519

People with hidden impairments

20,184

Elderly population ( $>65$ )

80,903

124,816

Source: OSSATE (2005)

\section{Corresponding author}

James Bowtell can be contacted at: j.bowtell@hotmail.co.uk

For instructions on how to order reprints of this article, please visit our website:

www.emeraldgrouppublishing.com/licensing/reprints.htm

Or contact us for further details: permissions@emeraldinsight.com 